\title{
STRATIGRAPHY OF HOLOCENE PEDIASTRUM TAXA FROM THE SEDIMENTS OF LAKE MAARDU, NORTH ESTONIA
}

\author{
Siim VESKI
}

Eesti Teaduste Akadeemia Geoloogia Instituut (Institute of Geology, Estonian Academy of Sciences), Estonia pst. 7, EE-0100 Tallinn, Eesti (Estonia)

\section{Presented by A. Raukas}

Received April 26, 1993; accepted September 17, 1993

Abstract. Data on the distribution of the green algae Pediastrum species in the Holocene were obtained from the sediments of Lake Maardu, North Estonia. The aim is to show the succession of taxa carrying different ecological information and discuss whether the trends in Pediastrum curves could be correlated with changes in the environment as inferred from other stratigraphic data. The ecological sensitivity of different Pediastrum taxa helps follow the changes in the lake water alkalinity, conductivity, pH, etc. and reconstruct the trophic level of the lake.

Key words: Pediastrum stratigraphy, lake sediments, Holocene, Lake Maardu, Estonia.

\section{INTRODUCTION}

The present paper was to a great extent inspired by personal contacts with Dr. Gertrud Cronberg, University of Lund, and by an excellent paper by Nielsen and Sørensen (1992).

While carrying out pollen analysis the author tried to register different Pediastrum species hoping to gain some ecological information. Although studies on green algae from water are carried out at different institutes, Pediastrum studies from lake sediments were unknown in Estonia up to the present. Thanks to the above-mentioned persons and to a great deal following their works the author is making an attempt to discuss this interesting problem.

Thanks to the content of sporopollenin in the cell walls, the coenobia of the green algae Pediastrum are usually well preserved in the sediments and able to withstand the general treatment used for pollen preparation. So when making pollen analyses of lake sediments, algal remains are often recorded together with pollen. Usually the pollen diagrams published in Estonia contain Pediastrum species counted as a group, and the percentage distribution of total Pediastrum is presented and used as an indicator of changes in hydrology and trophic conditions. However, in sediments Pediastrum is well preserved and can easily be identified to species level. 
The purpose of the present study is to

1. encourage pollen analysts and limnologists to register and identify Pediastrum to species level in sediment samples,

2. show the succession of taxa with different ecological information, otherwise unnoticeable while total Pediastrum is counted, and

3. elucidate whether the trends in Pediastrum curves could be correlated with changes in the environment as inferred from other stratigraphic data.

\section{METHODS}

The Pediastrum study is based on a sediment core taken with a Belarus sampler in 1991. Sediment columns of $1 \mathrm{~m}$ were wrapped in plastic film and transported to the laboratory for closer examination and sampling. Each centimetre was collected separately.

The samples were treated by the acetolysis method described by Erdtman (1936). Minerogenic samples were kept in hydrofluoric acid for some days. The material was stained with basic fuchsin and embedded in glycerin. Pediastrum analysis was carried out parallel with the pollen analysis from the same slides. A magnification of $\times 250$ was used for routine counting. All critical determinations were made by using $\times 1000$ magnification supported by phase contrast equipment. At least 1000 Arboreal Pollen (AP) grains were counted in each sample. Because of the abundance of Pediastrum coenobia in the sediments of Lake Maardu the total number of algae counted was greater. Generally 400 specimens per sample is considered reasonably sufficient (Battarbee, 1986). Five taxa were recorded. Only coenobia estimated to contain at least half of the number of cells were counted.

The curves of Pediastrum are expressed as relative frequencies of the total number of Pediastrum. In Veski (1992) the same Pediastrum values were counted against pollen sum. The basic picture is similar in both cases. A curve for total Pediastrum percentage values frequently used in pollen diagrams is also included illustrating the real value of the species level counting of Pediastrum.

Information on the ecology of Pediastrum taxa was obtained mainly from Nielsen \& Sørensen (1992), Cronberg $(1982,1986)$, Parra Barrientos (1979), and Huber-Pestalozzi (1983).

\section{MATERIAL AND DATING}

Lake Maardu is situated $15 \mathrm{~km}$ east of Tallinn on top of an ancient buried valley in the limestone bedrock. In the north the lake is dammed by an Ancylus beach ridge. The threshold of the lake is estimated to be $32 \mathrm{~m}$ a.s.1., which is indicative of its isolation during the Yoldia Sea regression. According to the pollen diagram interpretation and ${ }^{14} \mathrm{C}$ dates the isolation occurred in the second half of Pre-Boreal. From the data available it may be concluded that during the minimum Yoldia Sea level the lake was very shallow or even dry. During the Ancylus transgression the water level rose considerably (up to $35 \mathrm{~m}$ a.s. 1.) in the Maardu area and should have flooded the lake basin according to the threshold altitude. It is likely that the waters of the Ancylus Lake never reached the Lake Maardu basin directly as the beach ridge grew due to the reworking processes of the glaciofluvial heart of the ridge, which closes the klint bay, and the heavy sidewards erosion of the klint peninsulas. The formation of the beach ridge and the high ground water level in connection with the Ancylus transgression were favourable for the filling up of Lake 
Maardu. Since then the lake existed as an isolated water body with no in- or outlets until 1893 , when in order to improve the land productivity of the low areas around the lake a canal was dug towards the sea with a water gate system to regulate the lake water level. In 1894 water broke through the gates and the lake water ran into the sea leaving a muddy plain, which gradually overgrew with vegetation. The lake was dammed again in 1939 and today the surface area of the lake is 165 ha, mean depth $0.9 \mathrm{~m}$, max depth $3.0 \mathrm{~m}$, and the drainage area $14 \mathrm{~km}^{2}$.

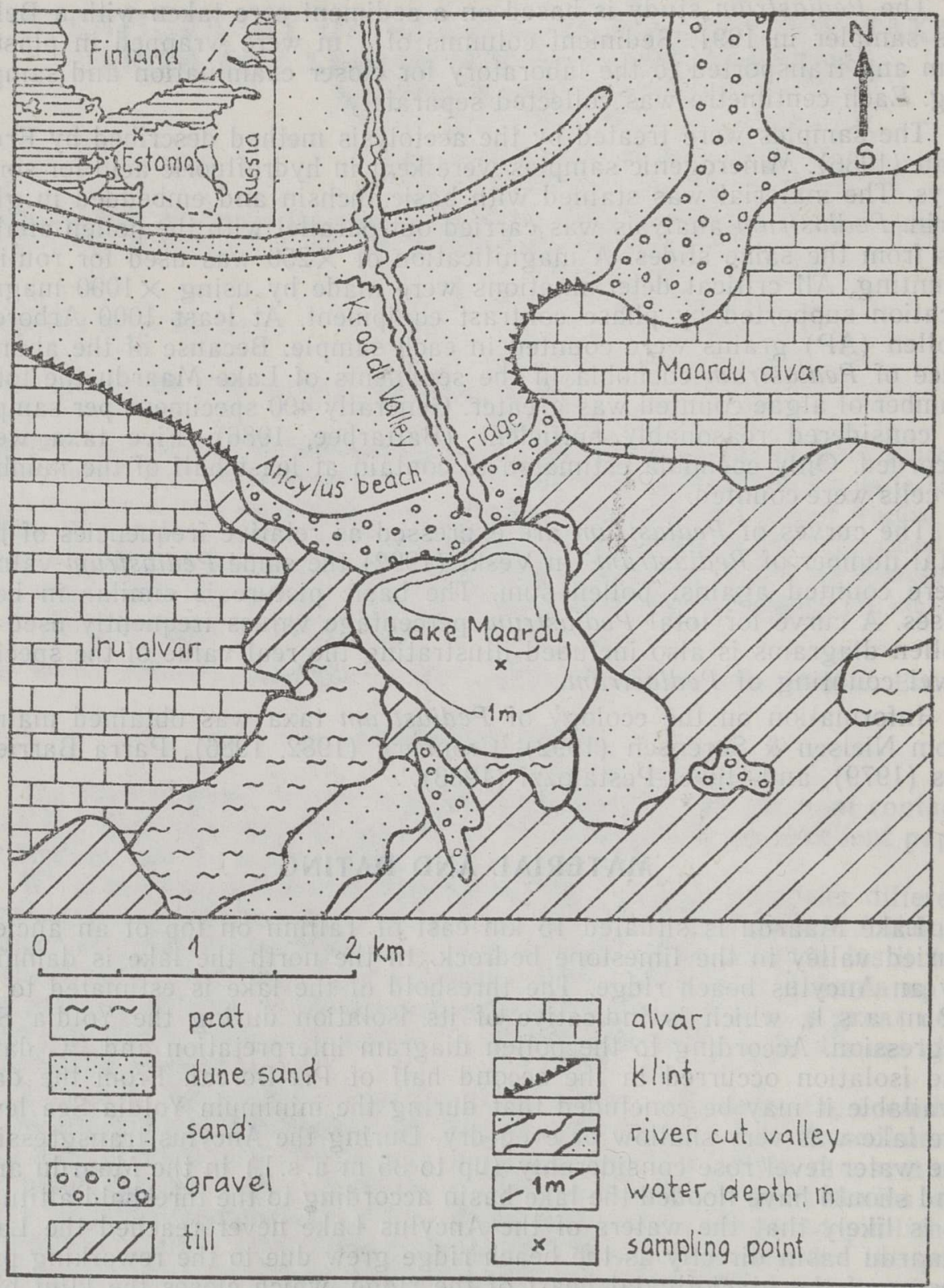

Fig. 1. Location of the study area and scheme of the Quaternary deposits in the vicinity of Lake Maardu, North Estonia, 
The vegetational history of the region (Veski, 1992) is recorded since $9500 \mathrm{BP}$ and covers almost the whole sequence of the Holocene. The ${ }^{14} \mathrm{C}$ dating of the material proved that the hard water effect (a major problem in North-Estonian lake sediments due to the limestone bedrock) is lacking or is of minor importance probably because of the relatively thick Quaternary deposits in the ancient buried valley and the fact that there were no stream inlets to the lake to transport allochthonous carbonates from the catchment area.

The samples were analysed from a core taken from the central part of Lake Maardu (Fig. 1), where the water depth was $0.90 \mathrm{~m}$.

Depth below

Description

sediments surface,

$\mathrm{m}$

$0.00-0.15$

Gyttja, calcareous, silty, greenish black, unconsolidated, with $\mathrm{H}_{2} \mathrm{~S}$ odour, lower $5 \mathrm{~cm}$ with plant remains.

$0.15-0.35$

Sod layer-gyttja penetrated by plant roots, brown, dark.

$0.35-1.00$

Gyttja, brown, upper part rich in plant roots, upper boundary diffuse.

$1.00-5.23$

$5.23-5.32$

$5.32-5.35$

$5.35-5.70$

Gyttja, olive brown. 4.90-5.23 m darker, more consolidated.

Gyttja, silty, greenish brown.

Sand, with some diffuse organic material, brown.

Sand, grey.

\section{RESULTS}

The results of palynology have been published earlier (Veski, 1992), therefore only some necessary comments on the vegetation history in the region are included.

\section{Pediastrum zones}

Zone A $(535-521 \mathrm{~cm})$. The zone is characterized by the dominance of Pediastrum boryanum $(90 \%)$, and the most abundant occurrence of $P$. angulosum at the bottommost part of the stratigraphy (Fig. 2.). P. duplex is registered in rather equal numbers throughout the diagram, with exceptions for some peaks. Minimal numbers of Pediastrum kawraiskyi are recorded in the zone, though they rise rapidly.

Zone B $(521-470 \mathrm{~cm})$. First maximum of Pediastrum kawraiskyi and $P$. duplex. Relatively low $P$. boryanum and $P$. angulosum graphs.

Zone C $(470-419 \mathrm{~cm})$. Rapid appearance of Pediastrum simplex and a gentle rise in the graph of $P$. angulosum are observed. $P$. boryanum and $P$. kawraiskyi remain at the same level.

Zone D $(419-341 \mathrm{~cm})$. High and still rising share of Pediastrum boryanum is observed, at the same time that of $P$. kawraiskyi is decreasing. The graphs of $P$. duplex and $P$. simplex are quite even. A slight rise of the $P$. angulosum graph occurs.

Zone E $(341-260 \mathrm{~cm})$. Second maximum of Pediastrum boryanum, low share of $P$. kawraiskyi. The graph of $P$. simplex is decreasing towards the upper zone border, that of $P$. angulosum keeps to high values, but decreases also at the upper zone limit. 


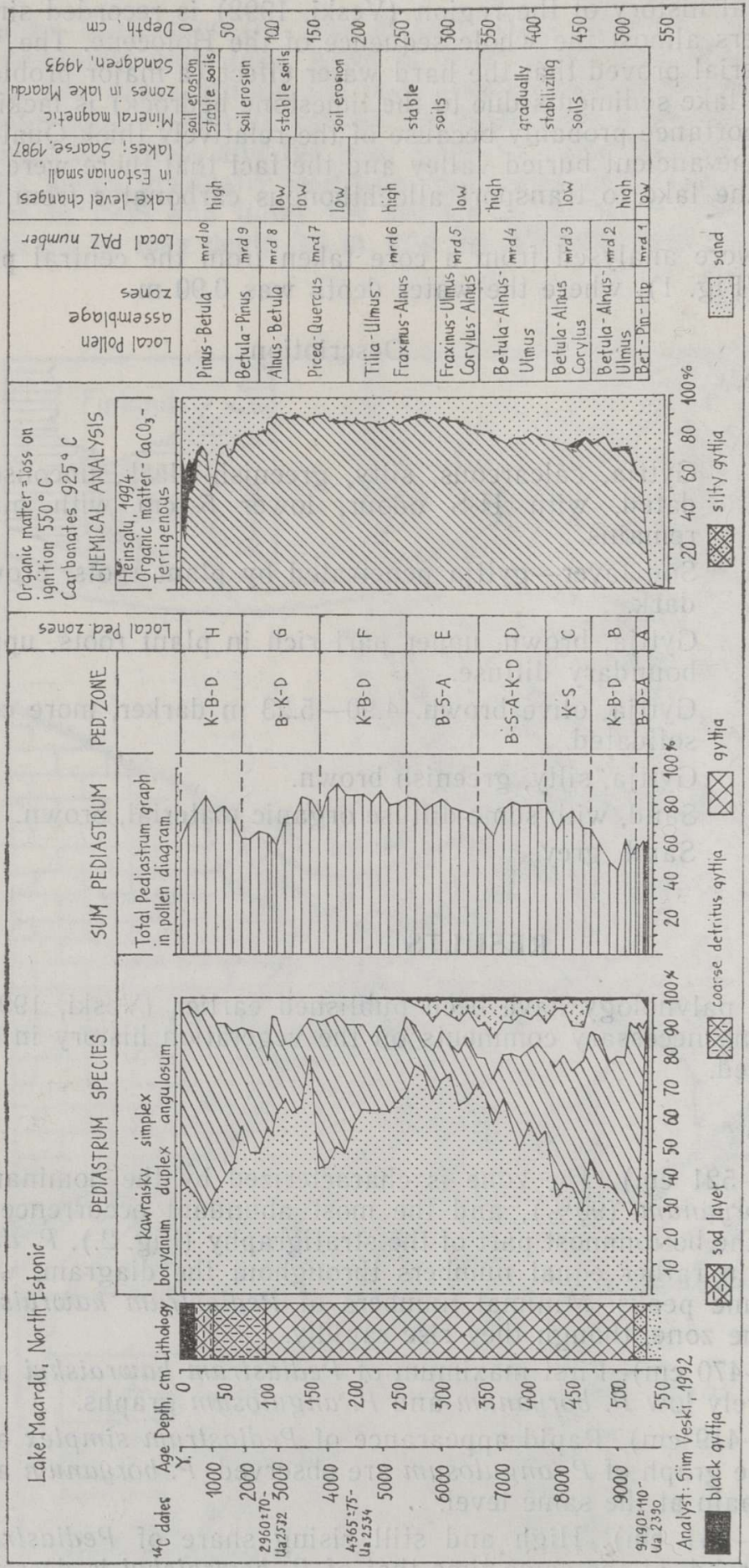

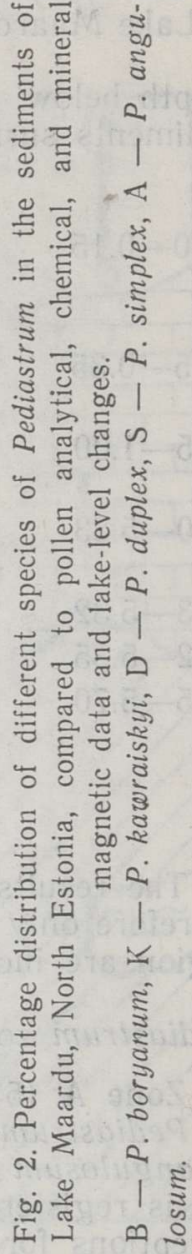


Zone F (260-160 cm). Pediastrum simplex and $P$. angulosum disappear. The graphs of $P$. boryanum and $P$. kawraiskyi have an opposite configuration, the former rises and the latter declines.

Zone G $(160-71 \mathrm{~cm})$. The zone is characterized by a peak of Pediastrum boryanum graph and a relatively low P. kawraiskyi graph. A slightly higher share of $P$. duplex is observed.

Zone $\mathrm{H}(71-0 \mathrm{~cm})$. Rising graph of Pediastrum kawraiskyi, the share of $P$. boryanum is still falling, only in the topmost samples it rises a little. The graph of $P$. duplex decreases gradually.

\section{DISCUSSION}

A summary of the ecological information for different Pediastrum species is given based on the above-mentioned publications.

Pediastrum boryanum (Fig. 3): The most widely distributed of all Pediastrum taxa today. Relatively indifferent to the trophic conditions in a

lake, although quantitatively more common in eutrophic waters.

Pediastrum kawraiskyi: Quite a rare species today. More common in the countries bordering on the Baltic Sea. Prefers oligotrophic waters with high conductivity in the temperate and polar areas. P. kawraiskyi has a correlation with high alkalinity rather than high productivity. More tolerant of low temperatures than most other taxa.

Pediastrum duplex: Prefers relatively warm and eutrophic conditions.

Pediastrum simplex: In neutral and slightly alkaline waters. More often in eutrophic conditions.

Pediastrum angulosum: A good indicator of oligotrophic conditions with low productivity and neutral to slightly acid waters. Termophilous.

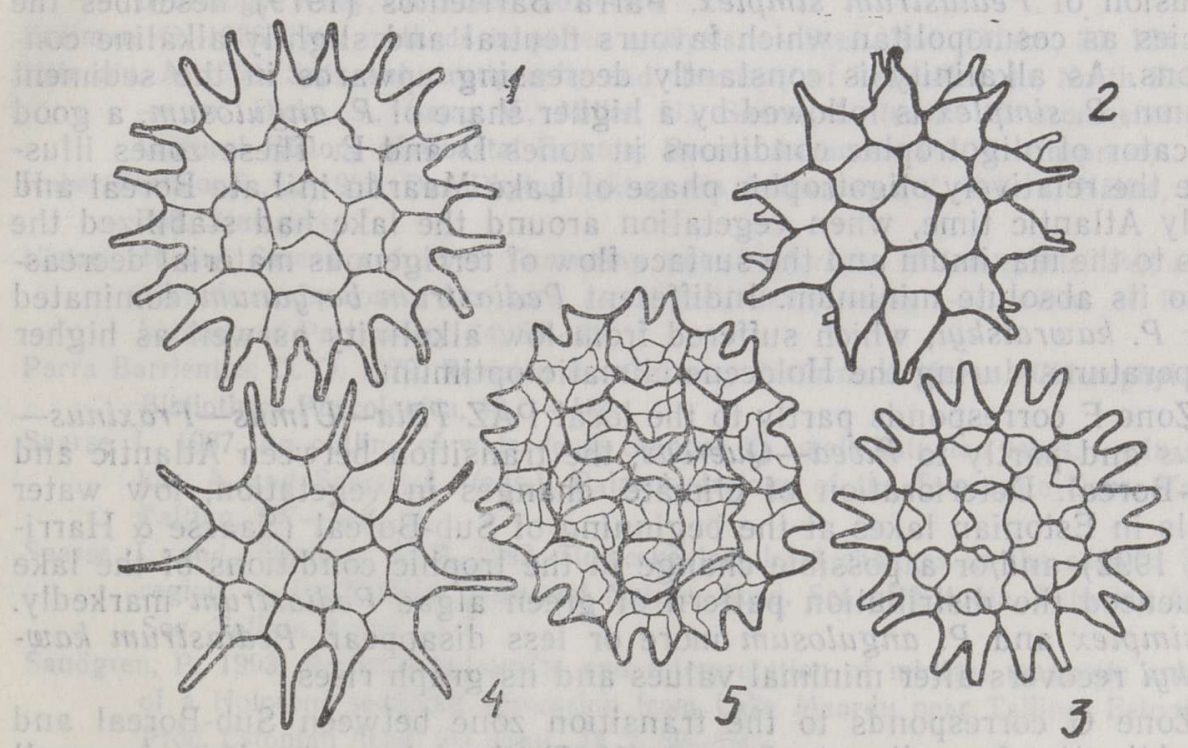

Fig. 3. The different species of Pediastrum observed in Lake Maardi: $1-P$. boryanum, $2-P$. kawraiskyi, $3-P$. duplex, $4-P$. simplex, $5-P$. angulosum. 
Zone A corresponds to the local pollen assemblage zone (PAZ) Betula-Pinus-Hippophae and belongs to the second half of Pre-Boreal. At that time the lake separated from the Baltic basin during the Yoldia Sea regression. Rather indifferent Pediastrum boryanum was the dominant species, a peak of $P$. angulosum at the bottom part of the sediment sequence could indicate an isolation from a larger basin. The zero values of $P$. kawraiskyi at the lowermost samples do not support the relict origin of the species. The high $P$. boryanum share could also indicate a redeposition from older sediments below gyttja.

Zone B corresponds to the local PAZ Betula-Alnus-Ulmus. The graph of Pediastrum kawraiskyi starts very abruptly with a marked peak, that of $P$. boryanum has fallen to its minimum. These reverse changes in the percentage values are also indicative of a hiatus in the sedimentation in early Boreal discussed in Veski (1992). P. kawraiskyi prefers oligotrophic waters with high conductivity and shows a correlation with higher alkalinity rather than high productivity (Crisman, 1978). In Lake Maardu sediments the graph of $P$. kawraiskyi follows the graph of organic matter- $\mathrm{CaCO}_{3}$-terrigenous matter surprisingly well. In spite of the fact that Lake Maardu is situated in a region with limestone bedrock and therefore should have hard water, an opposite situation is observed. Because of the lack of stream or river inlets to the lake and the sand infilling of the ancient buried valley on top of which the lake basin is situated the lake water is rather soft (low conductivity). Alkalinity of the lake water is controlled by the surface inflow of $\mathrm{HCO}^{-}$ions (limestone bedrock). In this way alkalinity and conductivity in the water of Lake Maardu are closely related to each other and to the input of terrigenous material into the lake. The curve of $P$. kawraiskyi copies the pattern of the curve of terrigenous material and $\mathrm{CaCO}_{3}$, thus supporting the ecological information of this species mentioned before. In zone B the share of $P$. kawraiskyi is high evidently due to the instability of soil (Sandgren, 1993) and the relatively open Boreal forest in the surroundings of Lake Maardu, conducive to the input of terrigenous material into the lake.

Zone C corresponds partly to the local PAZ Betula-Alnus-Corylus. The situation is rather similar to the previous zone except for the rapid intrusion of Pediastrum simplex. Parra Barrientos (1979) describes the species as cosmopolitan which favours neutral and slightly alkaline conditions. As alkalinity is constantly decreasing upwards in the sediment column, $P$. simplex is followed by a higher share of $P$. angulosum, a good indicator of oligotrophic conditions in zones D and E. These zones illustrate the relatively oligotrophic phase of Lake Maardu in Late Boreal and Early Atlantic time, when vegetation around the lake had stabilized the soils to the maximum and the surface flow of terrigenous material decreased to its absolute minimum. Indifferent Pediastrum boryanum dominated over $P$. kawraiskyi, which suffered from low alkalinity as well as higher temperatures during the Holocene climatic optimum.

Zone $\mathrm{F}$ corresponds partly to the local PAZ Tilia-Ulmus-FraxinusAlnus and partly to Picea-Quercus, the transition between Atlantic and Sub-Boreal. Deterioration of climate, changes in vegetation, low water levels in Estonian lakes at the beginning of Sub-Boreal (Saarse \& Harrison, 1992) and/or a possible change in the trophic conditions of the lake influenced the distribution pattern of green algae Pediastrum markedly. $P$. simplex and $P$. angulosum more or less disappear. Pediastrum kawraiskyi recovers after minimal values and its graph rises.

Zone $\mathrm{G}$ corresponds to the transition zone between Sub-Boreal and Sub-Atlantic. According to Saarse (1987) the lake water level in small Estonian lakes was low and Sandgren (1993) shows stable soil conditions around the lake. In addition a climatic deterioration and reforestation of 
the lake shore are described in Veski (1992). Pediastrum kawraiskyi shows minimum values. Shortly after that the graph of $P$. kawraiskyi starts to rise to its absolute maximum of $70 \%$ in zone $\mathrm{H}$, which is characterized by an increasing terrigenous material input and human impact in the vicinity of Lake Maardu.

\section{CONCLUSIONS}

1. Pediastrum analysis on species level enables to show the trends of Pediastrum species with different ecological information, thus helping reconstruct the trophic level of the lake, its alkalinity, conductivity, $\mathrm{pH}$, water depth, and other parameters.

2. The ecological information on Pediastrum species is not sufficient to rely on independently, but it works well in cooperation with other methods like pollen, diatom, and other phytoplankton analysis, i. e. chrysophyte cysts, chemical analyses, etc.

3. The pattern of Pediastrum simplex curve in the sediments of Lake Maardu supports the low alkalinity needs of the species, while its coexistence with $P$. angulosum in the sediments speaks of oligotrophic preference.

\section{REFERENCES}

Battarbee, R. W. 1986. Diatom analysis. - In: Berglund, B. E. (ed.). Handbook of Holocene Palaeoecology and Palaeohydrology. Wiley, Chichester, 527-570.

Crisman, T. L. 1978. Algal remains in Minnesota lake types: A comparison of modern and late-glacial distributions. - Verh. Int. Ver. Theor. Angew. Limnol., 20, $445-451$.

Cronberg, G. 1982. Phytoplankton changes in Lake Trummen induced by restoration. Folia Limnol. Scandinavica, 18, $1-119$.

Cronberg, G. 1986. Blue-green algae, green algae and Chrysophyceae in sediments. In: Berglund, B. E. (ed.). Handbook of Holocene Palaeoecology and Palaeohydrology. Wiley, Chichester, 507-526.

Erdtman, G. 1936. New methods in pollen analysis. - Sven. Bot. Tidskr., 30, 154-164.

Heinsalu, A. 1994. Sediment stratigraphy and chemistry of Lake Maardu, North Estonia. - In: Hicks, S., Lang, V., Miller, U., Saarse, L. (eds.). Environmental and Cultural History of Coastal Estonia: Recent Advances, PACT (in press).

Huber-Pestalozzi, G. 1983. Das Phytoplankton des Süßwassers, 7. Teil, 1. Hälfte, 283308. Stuttgart.

Nielsen, H. and Sørensen, I. 1992. Taxonomy and stratigraphy of late-glacial Pediastrum taxa from Lymosen, Denmark - A preliminary study. - Review of Palaeobotany and Palynology, 74, 55-75.

Parra Barrientos, O. O. 1979. Revision der Gattung Pediastrum Meyen (Chlorophyta). Bibliotheca Phycologica, 48, 1-184.

Saarse, L. 1987. An outline of water-level changes in small Estonian lakes. - In: Raukas, A. and Saarse, L. (eds,). Palaeohydrology of the Temperate Zone. Valgus, Tallinn, $137-146$.

Saarse, L. and Harrison, S. P. 1992. Holocene lake-level changes in the eastern Baltic region. - In: Estonia. Man and Nature. Acad. Sci. of Estonia, Estonian Geogr. Soc., Tallinn, 6-20.

Sandgren, P. 1993. Preliminary results and interpretation of mineral magnetic analyses of a Holocene sediment succession from Lake Maardu near Tallinn, Estonia. Proc. Estonian Acad. Sci. Geol., 42, 2, 69-79.

Veski, S. 1992. The Holocene development of Lake Maardu and the vegetational history of North Estonia. - Kvartärgeologiska Avdelningen, Uppsala Universitet, Rep. No. $165,1-41$. 


\title{
ROHEVETIKAS PEDIASTRUM'I LIIKIDE STRATIGRAAFIA MAARDU JÄRVE SETETES
}

\author{
Siim VESKI
}

Uudsena Eestis on Maardu järve setetes paralleelselt õietolmu analüüsiga määratud rohevetikate hulka kuuluva perekonna Pediastrum liike. Erinevalt tavalisest Pediastrum'i summaarsest loendamisest võimaldab Pediastrum'i liigiline määramine vähese töömahuga saada lisateavet vee sügavuse, leeliselisuse, elektrijuhtivuse, $\mathrm{pH}$ ning järvede troofsuse kohta. Meetod on lisaabinõu paleolimnoloogilistel rekonstruktsioonidel ning järvede nüüdisaegsel monitooringul.

\section{СТРАТИГРАФИЯ ВОДОРОСЛЕЙ РЕDIASTRUM В ГОЛОЦЕНЕ НА ПРИМЕРЕ ОТЛОЖЕНИЙ ОЗЕРА МААРДУ, СЕВЕРНАЯ ЭСТОНИЯ}

\section{Сийм ВЕСКИ}

На основе анализа зеленых водорослей рода Pediastrum оз. Маарду, проведенного совместно со спорово-пыльцевым анализом его отложений, впервые получены данные о распространении видов Pediastrum в голоцене Эстонии. Род Pediastrum обычно регистрируется суммарно, но отдельные виды Pediastrum, содержащие разную экологическую информацию, помогают нетрудоемким способом получить сведения о глубине, щелочности, электропроводности, рН воды, а также о степени трофности озер. Анализ дает дополнительные возможности для реконструкции палеосреды. 